\title{
Pembangunan Sistem Informasi Pengelolaan Data Transaksi Bagian Tambang PT. Yasiga Sarana Utama Berbasis Web dengan Fitur Mobile
}

\author{
Rahmi Prisalia ${ }^{1}$, Difana Meilani ${ }^{2}$, Hasdi Putra ${ }^{3}$, Husnil Kamil ${ }^{4}$
}

\begin{abstract}
Web-based management information system of transaction data with mobile features was needed by employees of PT. Yasiga Sarana Utama, especially mine division. The problems that frequently occur are some documents are created with the manual method, data storage is conducted using Microsoft Excel and duplication. Damage and loss of data have been solved with Web-based management information system of transaction data. In addition, the field employees who have activities outside of the Office get ease in storing and archiving the data using a mobile application integrated with transaction data management information systems. Management information system of transaction data was built using the waterfall method which consisted of the analysis, design, coding or implementing, and testing. In the early stages of development, the company business processes were studied through literatures, and then the company requirements were analyzed using use case diagrams, class diagrams, sequence diagrams, state chart diagrams, and user interface design. The next phase was the design of the system by designing a database using the ERdiagrams. Programming code on the implementation phase was conducted using PHP PDO with object-oriented programming, Bootstrap PostgreSQL database as an additional aesthetic applications, and PhoneGap to generate mobile applications. Application testing was conducted using black box testing. The results of the implementation showed the expected output and in accordance with existing business processes.
\end{abstract}

Keywords-Management Information System of Transaction Data, PT. Yasiga Sarana Utama, Mobile, Waterfall

Intisari- Sistem informasi pengelolaan data transaksi berbasis web dengan fitur mobile sangat diperlukan oleh karyawan PT. Yasiga Sarana Utama, khususnya bagian tambang. Permasalahan yang terjadi seperti dokumen yang masih dibuat dengan cara manual, penyimpanan data masih dilakukan dengan Microsoft Excel serta duplikasi, kerusakan dan kehilangan data telah teratasi dengan adanya sistem informasi pengelolaan transaksi ini. Selain itu, karyawan lapangan yang memiliki aktivitas di luar kantor mendapatkan kemudahan dalam menyimpan dan merekap data dengan menggunakan aplikasi mobile yang terintegrasi dengan sistem informasi pengelolaan data transaksi.

Sistem informasi pengelolaan data transaksi ini dibangun dengan menggunakan metode waterfall yang terdiri dari analisis,

\footnotetext{
${ }^{1}$ Alumnus, Jurusan Sistem Informasi Universitas Andalas Alamat: Perumahan Permata Air Dingin Blok D no.5 Lubuk Minturun Padang 25175 INDONESIA. e-mail: driveallin.rahmi@yahoo.com

${ }^{2}$ Dosen, Jurusan Teknik Industri Fakultas Teknik Universitas Andalas, Kampus Limau Manis Padang 25163 INDONESIA; email:difana@ft.unand.ac.id

${ }^{3,4}$ Dosen, Jurusan Sistem Informasi Fakultas Teknologi Informasi Universitas Andalas, Kampus Limau Manis Padang 25163 INDONESIA; e-mail ${ }^{3}$ : hasdiputra@fti.unand.ac.id; $e$-mail ${ }^{4}$ : husnil.k@gmail.com
}

perancangan, pengkodingan atau implementasi, dan pengujian. Pada tahap awal pembangunan penulis melakukan studi literatur tentang proses bisnis perusahaan, kemudian menganalisis kebutuhan dari perusahaan tersebut menggunakan use case diagram, class diagram, sequence diagram, statechart diagram, dan rancangan user interface. Tahap berikutnya yaitu perancangan sistem dengan merancang database menggunakan ER-diagram. Tahap pembuatan kode program menggunakan PHP PDO dengan memakai object-oriented programming, database PostgreSQL dan Bootstrap sebagai tambahan estetika aplikasi, serta PhoneGap untuk menghasilkan aplikasi mobile. Pengujian dilakukan dengan metode black box. Hasil dari implementasi yang telah dilakukan menunjukkan keluaran yang diharapkan dan sesuai dengan proses bisnis yang ada.

Kata Kunci-Sistem Informasi Pengelolaan Data Transaksi, PT.Yasiga Sarana Utama, Mobile, Waterfall

\section{Pendahuluan}

Pemakaian komputer adalah penting bagi organisasi sebagimana pentingnya model transaksinya. Untuk kegiatan transaksi yang banyak, cepat, dan teliti sangat memerlukan komputer. Tanpa komputer, efisiensi sulit dicapai, biaya operasional besar dan keuntungan cenderung akan menurun [1]. Tidak hanya komputerisasi yang dilakukan oleh suatu organisasi dalam memberikan efisiensi terhadap tujuan mereka, kemampuan untuk memperoleh informasi dapat ditunjang dengan adanya internet. Perkembangan internet dengan kecepatan aksesnya yang semakin meningkat mengakibatkan perolehan data atau informasi dapat dilakukan secara cepat dan tepat pada halaman web perusahaan. Hal ini didukung oleh sistem komputerisasi dokumen yang memberikan dukungan penuh terhadap kecepatan akses ke informasi dalam dokumen organisasi [2]. Selain aplikasi berbasis web, aplikasi berbasis mobile juga dapat menjadi alternatif bagi perusahaan untuk menunjang mobilitasnya. Menurut Reaserch In Motion (RIM) Asia Pasifik, pangsa pasar smartphone di Indonesia terus meningkat sejak 2010 dari $11 \%$ menjadi $24 \%$ pada 2014 [3]. Kebutuhan aplikasi mobile akan semakin meningkat seiring dengan meningkatnya pemakaian smartphone dalam menunjang produktivitas pemakainya.

Pengelolaan data transaksi yang selama ini dilakukan secara konvensional serta penyimpanan data keluaran transaksi yang menggunakan banyak ruang untuk penyimpanan datanya, dapat diubah menjadi pengelolaan data secara digital dengan mengandalkan sistem database pada komputer. PT Yasiga Sarana Utama (PT. YSU) merupakan salah satu perusahaan dagang yang bergerak dalam bidang jual-beli material tambang. Perusahaan ini memiliki bagian khusus yang menangani masalah transaksi jual-beli bahan baku, yaitu bagian tambang dan varia usaha. Transaksi pada 
bagian ini terjadi setiap jam sehingga pelaporan datapun semakin sering. Penyimpanan data perusahaan masih dilakukan dengan Microsoft Excel sehingga terjadi kemungkinan redudansi dan duplikasi data. Oleh karena itu, perlu dibangun Sistem Informasi Pengelolaan Transaksi Bagian Tambang pada PT Yasiga Sarana Utama ini.

\section{KAJIAN LITERATURE}

\section{A. Transaksi}

Transaksi adalah suatu pertemuan antara 2 pihak (penjual dan pembeli) yang saling menguntungkan, yang berdasarkan data/bukti/dokumen pendukung lalu dimasukkan ke jurnal setelah melalui pencatan [4]. Dalam istilah akuntansi, transaksi dapat dikatakan sebagai suatu kejadian yang dapat mempengaruhi posisi keuangan dari suatu badan usaha dan sebagai hal yang wajar untuk dicatat.

\section{B. PHP Data Object (PDO)}

PHP data objects (PDO) merupakan ekstensi dari PHP 5 yang memiliki library koneksi DBMS yang ringan. PDO ini mendukung beberaapa database yang membentuk API sendiri untuk menjalankan beberapa fungsi, dengan menggunakan fitur prepare statement dan error handling [5]. PDO dapat digunakan tanpa mengubah skrip pemograman yang telah dibuat.

\section{Bootsrap}

Bootstrap merupakan framework web developing yang responsif untuk semua device dan gadget dalam melakukan akses website maupun webapps [6].

\section{PostgreSQL}

PostgreSQL merupakan Object Relational Database Management System yang bersifat open source yang bias digunakan untuk kebutuhan data yang besar [7]. Website resmi PostgreSQL menyatakan bahwa database PostgreSQL memiliki dukungan penuh untuk foreign key, joins, view, triggers, dan stored procedures.

\section{E. PhoneGap}

PhoneGap merupakan tools yang digunakan untuk membuat aplikasi native yang digunakan pada perangkat mobile menggunakan teknologi web seperti CSS, HTML dan JavaScript [8]. Phonegap dapat menghasilkan native untuk beberapa sistem operasi mobile seperti android, blackberry, dan iOS.

\section{METODE PENELITIAN}

Metode yang digunakan dalam penelitian ini adalah studi literatur dan pengumpulan data di lapangan. Pengumpulan data dilakukan dengan melakukan wawancara langsung kepada pihak PT.Yasiga Sarana Utama tentang kegiatan transaksi yang berlangsung, pengumpulan dokumen terkait kegiatan transaksi dan studi kepustakaan terkait dengan transaksi.

Sedangkan metode pengembangan perangkat lunak yang digunakan untuk membangun sistem pengelolaan transaksi dengan fitur mobile ini adalah metode waterfall. Metode ini memiliki tahapan yaitu kebutuhan sistem, spesifikasi kebutuhan perangkat lunak, perancangan perangkat lunak, implementasi perangkat lunak, pengujian perangkat lunak, dan perawatan perangkat lunak [9]. Setiap tahapan mempunyai nilai resiko masing-masing dan jika salah satu tahapan menghadapi resiko dan timbul suatu masalah, maka pengerjaan akan kembali ke tahap sebelumnya. Tahapan metode ini dapat dilihat pada Gambar 1.

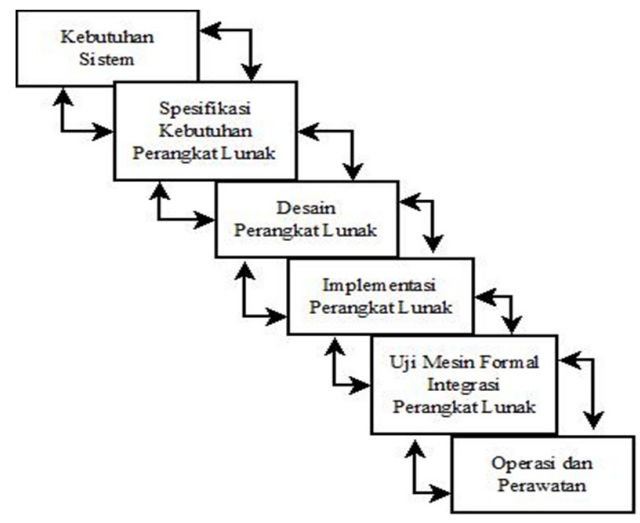

Gambar 1. Metode Waterfall [10]

\section{ANALISIS SISTEM}

Hasil analisis sistem digambarkan dengan Bussiness Process Model Notation (BPMN), Use Case Diagram, Skenario Use-Case dan Sequence Diagram sebagai berikut:

\section{A. $B P M N$}

BPMN merupakan notasi pemodelan secara grafis untuk proses bisnis yang independen dari lingkungan implementasi spesifik [10]. BPMN memberikan manfaat terhadap perusahaan agar dapat melihat proses bisnis yang mereka jalani secara lebih nyata. Gambar 2 merupakan BPMN transaksi jual beli material tambang. Sedangkan Gambar 3 adalah BPMN penagihan dan pembayaran.

Proses pembayaran dan penagihan yang terjadi di PT YSU adalah sebagai berikut:

- $\quad$ PT. YSU membuat invoice berdasarkan bukti timbangan yang diterima dari pihak klien

- $\quad$ PT. YSU memberikan invoice ke bagian keuangan

- Bagian keuangan menerima invoice dan membuat faktur

- Bagian keuangan melakukan penagihan kepada klien

- Pelanggan menerima bukti penagihan dari tim keuangan

- Pelanggan melakukan pembayaran di bank

- Pelanggan menerima bukti pembayaran dari bank 


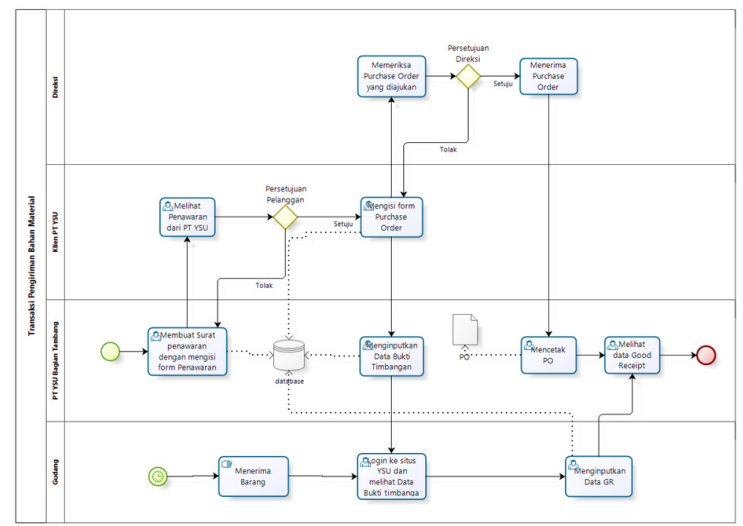

Gambar 2. BPMN Transaksi Pembelian/ Purchase Order Material

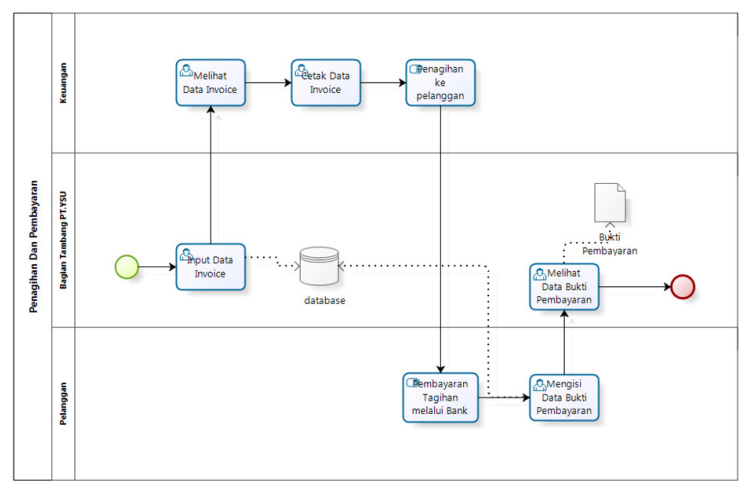

Gambar 3. BPMN Penagihan dan Pembayaran

\section{B. Use Case Diagram}

Pada sistem yang dibangun oleh penulis terdapat 6 aktor dan 25 use-case. Hasil use case yang dirancang dapat dilihat pada Gambar 4.

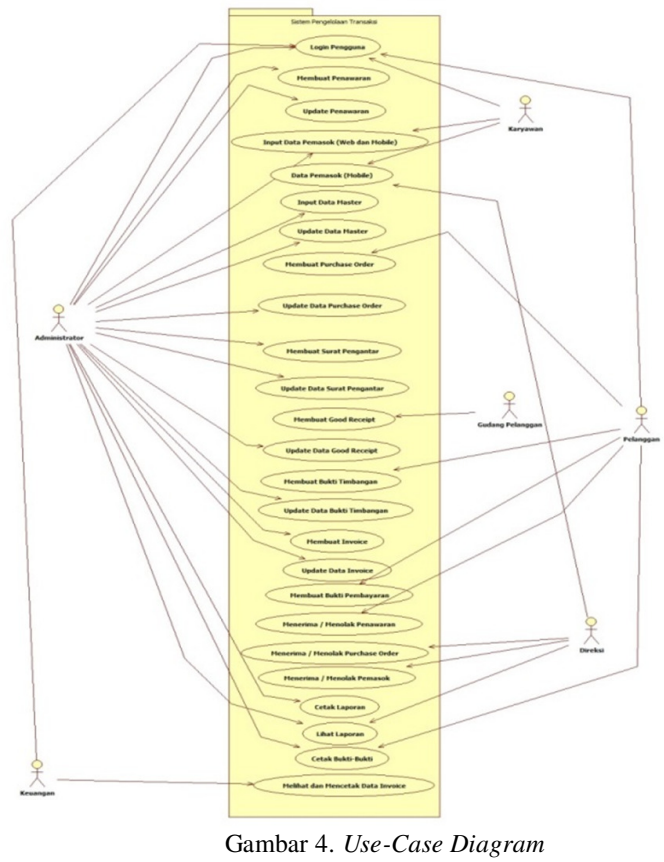

\section{Skenario Use-Case}

Skenario use-case merupakan penggambaran aksi dan reaksi dari yang dilakukan aktor terhadap sistem. Pada kegiatan sistem pengelolaan traksaksi ini. Skenario tersebut dapat dilihat pada Tabel I.

TABEL I

SKenario Use CASE PEMBELIAN DAN PURCHASE ORDER

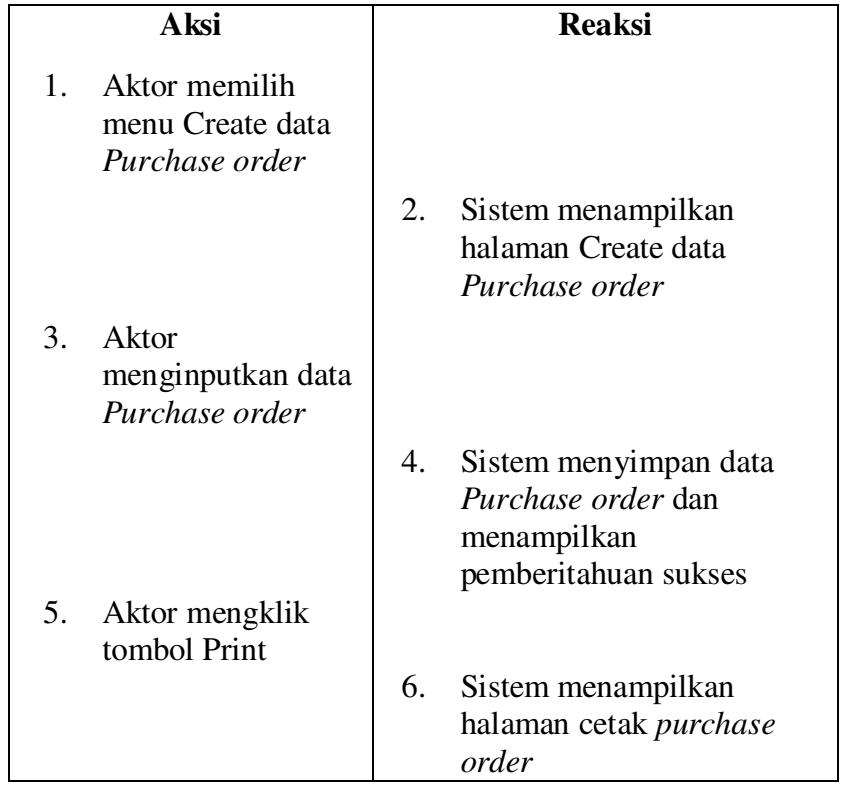

\section{Sequence Diagram}

Sequence diagram menggambarkan tahapan-tahapan yang dilalui sistem ketika aktor melakukan suatu tindakan pada sistem. Contoh salah satu sequence diagram yang terdapat pada sistem ini adalah sequece diagram input data pembelian atau purchase order seperti pada Gambar 5.

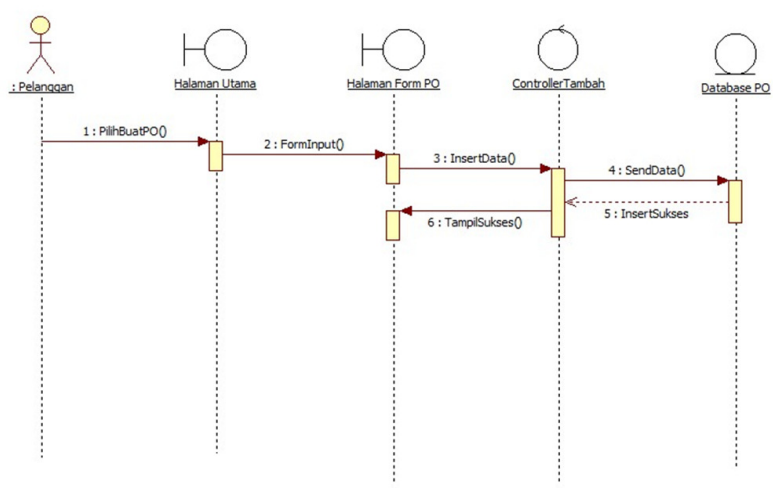

Gambar 5. Sequece Diagram Input Data Pembelian/ Purchase Order

\section{PERANCANGAN SISTEM}


Untuk perancangan sistem dilakukan dengan membuat rancangan Entity Relational Diagram (ERD), arsitektur perangkat lunak, statechart diagram, class diagram dan user interface.

\section{A. $E R D$}

Perancangan ERD merupakan rancangan terdapat tabeltabel yang akan digunakan didalam sistem yang hubungannya antara satu dengan lain. Perancangan tabel dilakukan sesuai dengan proses bisnis yang ada. Perancangan ERD dapat dilihat pada Gambar 6.

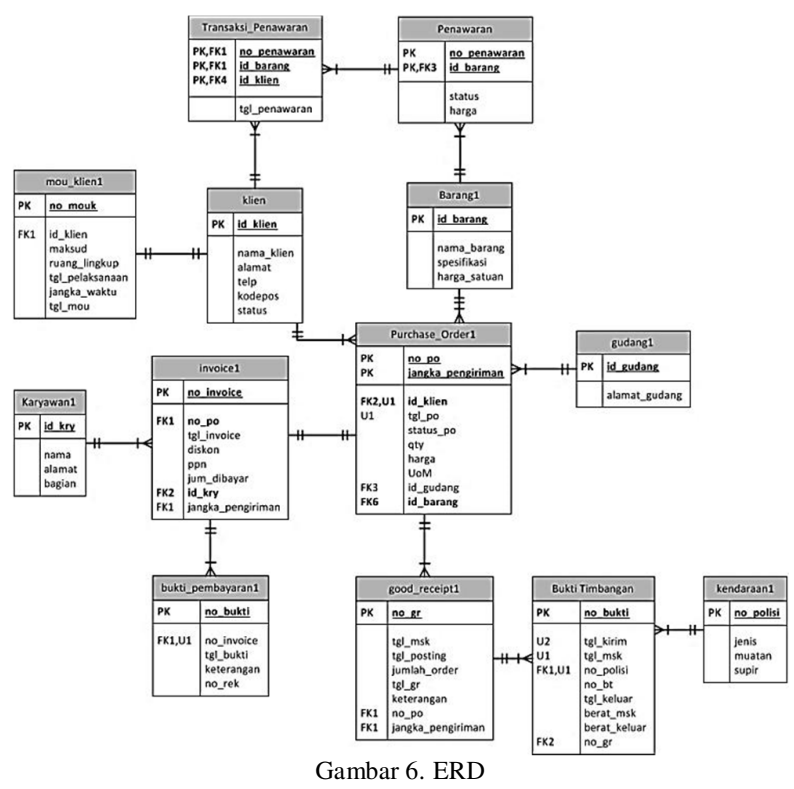

\section{B. Arsitektur Perangkat Lunak}

Pembangunan aplikasi ini menggunakan arsitektur 3-tier. Arsitektur 3-tier memecah komputasi menjadi 3 lapisan [11]. Terdapat lapisan tambahan middletier yang bertugas mengelola application/business logic yang memiliki tugas seperti rumus perhitungan. Penggambaran dari arsitektur 3tier dapat dilihat seperti pada Gambar 7.

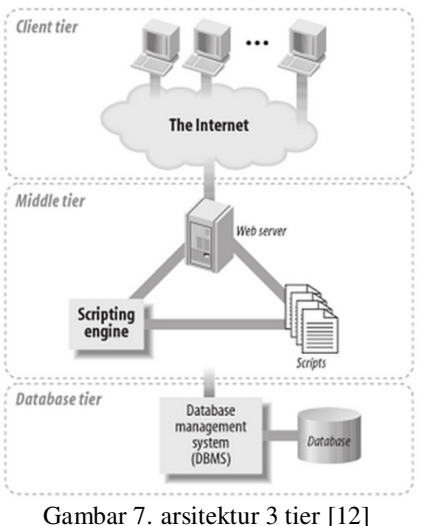

Gambar 7. arsitektur 3 tier [12]

\section{Statechart Diagram}

Statechart diagram digunakan untuk menggambarkan perubahan keadaan dari suatu proses ke proses lain. Statechart diagram dapat dilihat pada Gambar 8 .

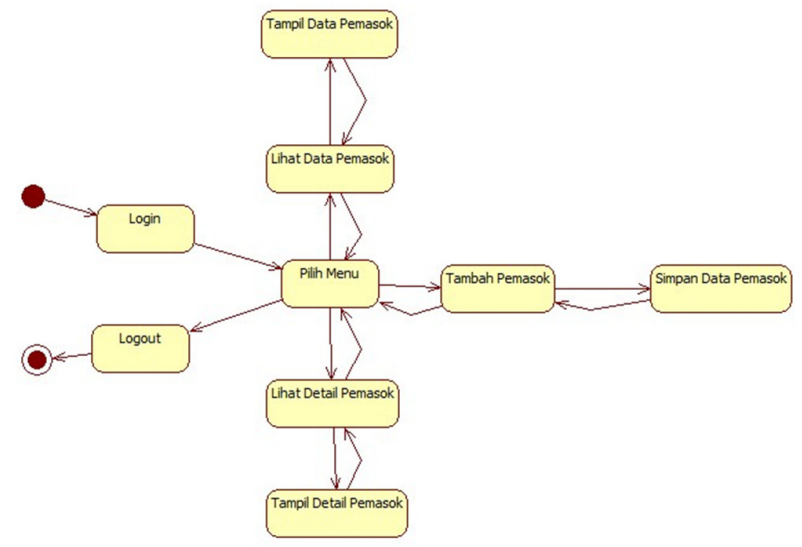

Gambar 8. StateChart Diagram

\section{Class diagram}

Rancangan kelas diagram menguraikan tentang bagianbagian dari suatu sistem serta hubungannya antara satu dengan yang lainnya dalam pembangunan perangkat lunak ini. Class diagramnya dapat dilihat pada Gambar 9.

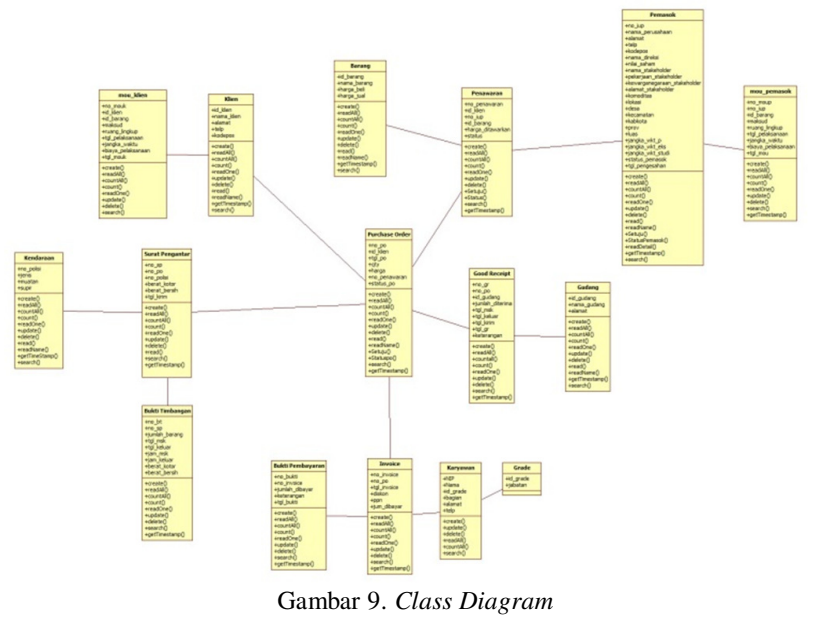

E. User Interface

Berikut ini merupakan rancangan untuk user interface pada perangkat lunak yang dibangun. User interface data pembelian atau purchase order untuk versi web dapat lihat pada Gambar 10 dan rancangan user interface versi mobile untuk lihat data pemasok pada Gambar 11. 


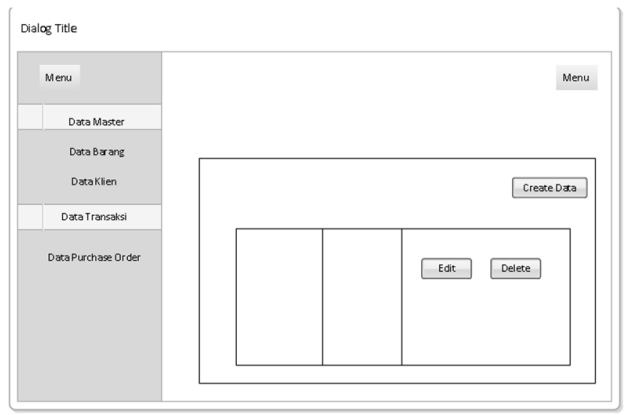

Gambar 10. User Interface Lihat Data Pembelian PO

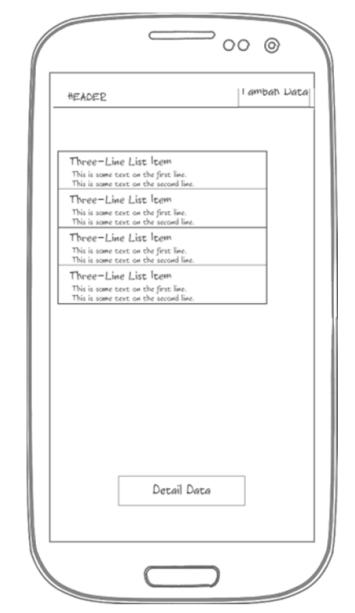

Gambar 11. User Interface Lihat Data Pemasok

\section{IMPLEMENTASI DAN PENGUJIAN}

Setelah melakukan perancangan sistem, selanjutnya dilakukan implementasi dan pengujian terhadap sistem informasi pengelolaan transaksi yang telah selesai dibangun.

\section{A. Implementasi Sistem}

Implementasi sistem terdiri dari 3 bagian, yaitu tampilan aplikasi versi web, tampilan aplikasi versi mobile dan kode program. Database diimplementasikan pada PostgreSQL dan untuk mobile menggunakan Jquery Mobile dan Javascript. Tampilan pembelian atau purchase order untuk aplikasi web dapat dilihat pada Gambar 12. Untuk tampilan mobile dan kode program dapat dilihat pada Gambar 13 dan Gambar 14.

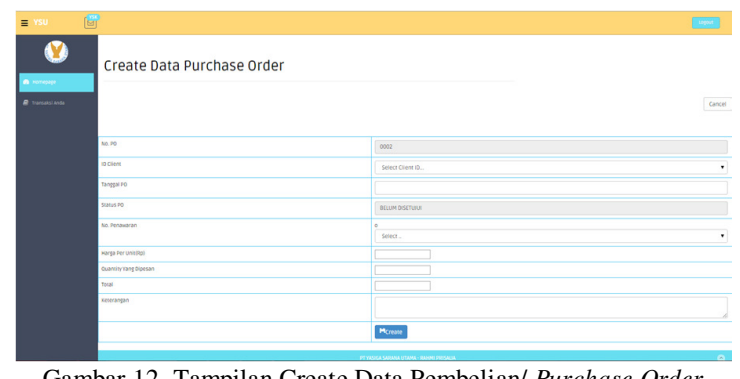

Gambar 12. Tampilan Create Data Pembelian/ Purchase Order

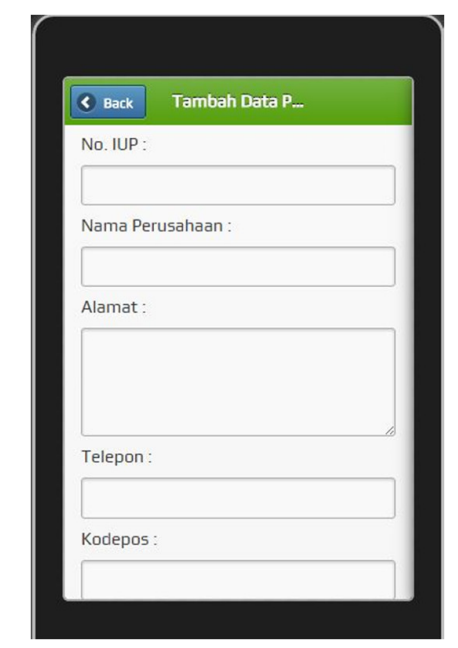

Gambar 13. Tampilan Tambah Data Pemasok

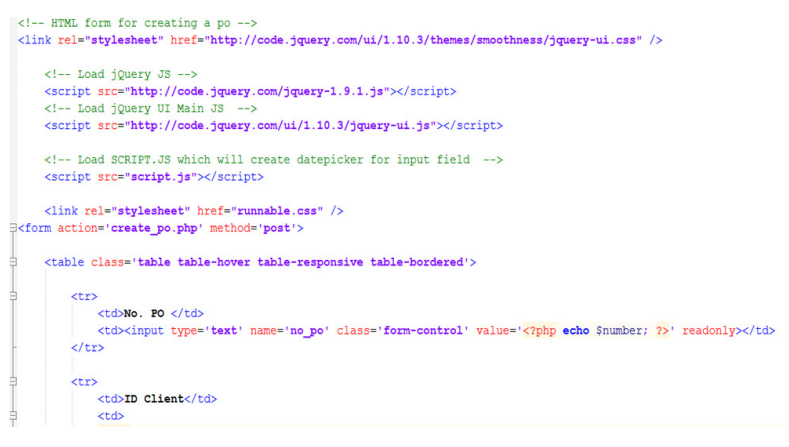

Gambar 14. Tampilan Kode Program

\section{B. Pengujian Sistem}

Pengujian dilakukan untuk menguji perangkat lunak yang dibangun berjalan sesuai dengan yang diharapkan. Metode pengujian yang digunakan adalah metode pengujian black box, yaitu pengujian yang dilakukan dengan menjalankan atau mengeksekusi unit atau modul, kemudian diamati hasil dari unit sesuai dengan proses bisnis yang diinginkan [13]. Hasil pengujian dilakukan dengan menguji kasus dan melihat hasil uji yaitu memasukkan data dalam keadaan benar atau data yang sesuai menurut sistem dan memasukkan data dalam keadaan salah atau data yang tidak sesuai menurut sistem. Tabel II merupakan salah satu rincian pengujian sistem, yaitu mengelola data surat pengantar untuk kegiatan input data, dengan memasukkan data dengan keadaan benar dan salah untuk melihat tanggapan yang diberikan sistem. Gambar 15, Gambar 16, Gambar 17 merupakan pembuktian bahwa data yang diinputkan melalui sistem sama dengan data yang dihasilkan dan diinputkan ke dalam database secara manual. 
TABEL II

Hasil Pengujian Pembelian / Purchase Order

\begin{tabular}{|c|c|}
\hline \multicolumn{2}{|c|}{ Kasus dan hasil uji dalam input data purchase order } \\
\hline $\begin{array}{l}\text { Data } \\
\text { masukan }\end{array}$ & Data diisi lengkap \\
\hline $\begin{array}{l}\text { Keadaan } \\
\text { yang } \\
\text { diharapkan }\end{array}$ & $\begin{array}{l}\text { Data berhasil ditambah ke dalam database } \\
\text { dan tampil pada halaman Read Data } \\
\text { Purchase Order }\end{array}$ \\
\hline Pengamatan & $\begin{array}{l}\text { Data berhasil disimpan ke dalam database } \\
\text { dan tampil pada halaman Read Data } \\
\text { Purchase Order }\end{array}$ \\
\hline Kesimpulan & Diterima \\
\hline \multicolumn{2}{|c|}{ Kasus dan hasil uji dalam keadaan salah } \\
\hline $\begin{array}{l}\text { Data } \\
\text { masukan }\end{array}$ & $\begin{array}{l}\text { Data yang diisikan tidak lengkap atau } \\
\text { pengguna salah memasukkan data sesuai } \\
\text { dengan kolomnya }\end{array}$ \\
\hline $\begin{array}{l}\text { Keadaan } \\
\text { yang } \\
\text { diharapkan }\end{array}$ & Data gagal ditambah dan muncul pesan error \\
\hline Pengamatan & $\begin{array}{l}\text { Data gagal disimpan ke database dan muncul } \\
\text { pesan error }\end{array}$ \\
\hline Kesimpulan & Diterima \\
\hline
\end{tabular}

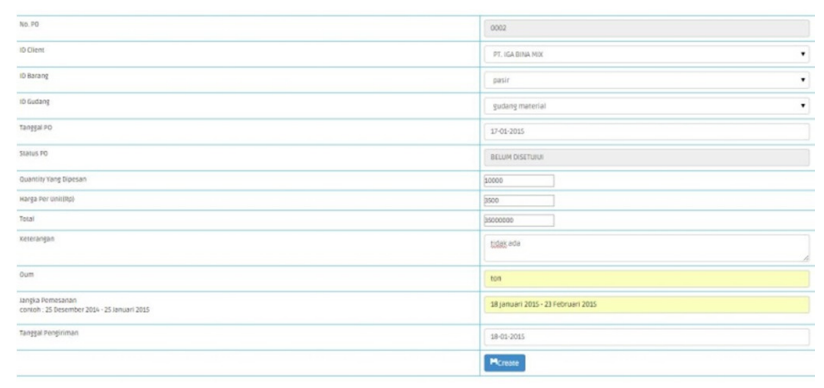

Gambar 15. Pengujian Input Data Pembelian/ Purchase Order

SQL

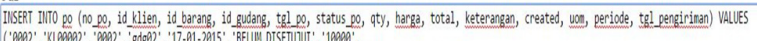

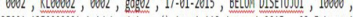

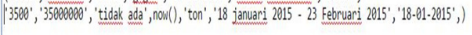

Gambar 16. Query SQL Input Data Pembelilan Purchase Order

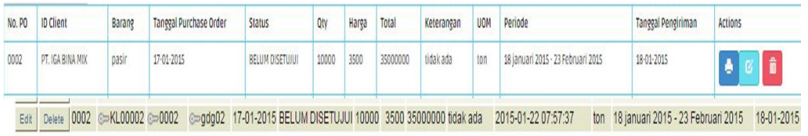

2row(s)

Gambar 17. Hasil Input Data Pembelian/ Purchase Order

\section{KESIMPULAN}

Aplikasi Sistem Informasi Pengelolaan Transaksi PT.Yasiga Sarana Utama bagian Tambang telah berhasil dibangun dengan menggunakan metode waterfall yang terdiri dari tahapan analisis, perancangan, coding dan pengujian. Proses bisnis pada kegiatan pengelolaan transaksi meliputi perjanjian kerjasama PT. Yasiga Saran Utama dengan pelanggan dan pihak pemasok, proses pengiriman material dan proses penagihan dan pembayaran. Tahap analisis sistem menggunakan beberapa diagram pembantu untuk menggambarkan proses kegiatan transaksi, yaitu BPMN
(Bussiness Process Model Notation), use case, sequence diagram, dan skenario use case. Tahap perancangan sistem menggunakan proses normalisasi form, penggambaran entitas menggunakan ER-diagram (Entity Relational Diagram), arsitektur perangkat lunak, statechart diagram, diagram kelas, dan user interface. Untuk tahapan implementasi aplikasi web telah berhasil dibangun dengan menggunakan pemrograman PHP berorientasikan objek dengan fitur PDO dan database postgreSQL serta web hosing. Sedangkan implementasi aplikasi mobile menggunakan phonegap dengan tampilan jquery mobile. Pengujian menggunakan metode black box. Dari pengujian yang dilakukan menunjukkan bahwa aplikasi yang dibangun sudah sesuai dengan proses bisnis dan kebutuhan fungsional yang diharapkan.

\section{REFERENSI}

[1] Amsyah, Z. (1997). Manajemen Sistem Informasi. Jakarta: Gramedia Pustaka Utama.

[2] Sukoco, B. M. (2007). Manajemen Administrasi Perkantoran Modern. Jakarta: Penerbit erlangga.

[3] Yudistira, Y. (2011). Membuat Aplikasi Iphone, Android \& Blackberry. Jakarta.

[4] Bastian, I. (2006). Akuntansi Pendidikan. Jarkarta: Penerbit Erlangga.

[5] Popel, Dennis.Learning PHP Data Objects. Packt Publishing Ltd, 2007.

[6] w3school.com Retrieved October 20, 2014, from https://www.w3school.com.

[7] Adam, A. L. (2004). PHP \& PostgreSQL. Yogyakarta: Andi.

[8] Wargo,John M.2012. PhoneGap Essentials: Building Cross-platform Mobile Apps. Addison-Wesley Professional: United States.

[9] Simarmata, Janner. Rekayasa Perangkat Lunak. 2010. Penerbit Andi : Yogyakarta.

[10] Bridgeland, D. M. (2009). Business Modeling: A Practical Guide to Realizing Business Value. U.K: Elsevier.inc.

[11] Fauzi, A. M. (2012). Pemrograman Database Visual Basic 6 dan Database SQL Server 2000. Yogyakarta: Penerbit Andi.

[12] Williams, H. E. (2004). Web Database Applications with PHP and $M y S Q L$. O'Reilly Media, Inc.

[13] Al Fatta, H. (2007). Analisis dan Perancangan Sistem Informasi untuk Keunggulan Bersaing Perusahaan dan Organisasi Modern. Yogyakarta: Andi Offset. 